\title{
INFORMATION AND COMMUNICATION TECHNOLOGIES AS A MEANS OF FORMING ECONOMIC COMPETENCE OF FUTURE VOCATIONAL TRAINING TEACHERS IN HIGHER EDUCATION INSTITUTIONS
}

\section{Liliia Syrotenko ${ }^{1}$}

DOI: https://doi.org/10.30525/978-9934-588-39-6-14

Ukraine is now involved in State-building processes that cover all spheres of its life. These processes are also important for higher education. According to the legislative framework of Ukraine, and «National Strategy for the Education Development in Ukraine for 2012-2021» in particular, the main directions, priorities, tasks and mechanisms of implementation of the state policy in the sphere of education are determined, and together with personnel and social policy form the basis for amendments and additions to the current legislation of Ukraine, as well as to management and financing, structure and content of the education system. Development of the National Strategy for the Education Development is necessitated by the profound changes aimed at improving the quality and competitiveness of education, solving strategic challenges faced by the national education system within new economic and socio-cultural conditions, its integration into the European and global educational space. Education is one of the most important spheres of Ukrainian state policy. The state now understands that education is a strategic resource of socio-economic, cultural and spiritual development of the society, resource aimed at improving the welfare of people, securing national interests, strengthening international authority and forming a positive image of our state, creating the conditions for self-realization of each individual [2, p. 6].

Dynamic changes are peculiar for the current stage of social development marked by the formation of a new educational paradigm, which is designed for the individual development of a human in the world. Accordingly, the requirements for the professional preparation of future vocational training teachers are changing. A modern teacher should become a qualified specialist who knows not only his subject well, but is also capable of various professional and socio-cultural activities, creative self-development.

Mastering modern information and communication technologies, methods of their usage in the educational process will contribute to the education modernization, i.e. improving the quality of a future specialist professional training, increasing the availability of education, meeting the needs of society

\footnotetext{
${ }^{1}$ Oleksandr Dovzhenko Hlukhiv National Pedagogical University, Ukraine
} 
in competitive professionals. A significant role in ICT introduction in the education process was played by the Law of Ukraine «On National Informatization Program» within the framework of which several projects of educational institutions informatization were implemented [1, p. 2].

The relevance lies in the introduction of modern information and communication technologies which is now the priority of educational development. They ensure the improvement of the educational process, accessibility and effectiveness of education in the preparation of future vocational training teachers.

According to the paragraph 3.5 «Informatization of Education» of the «National Strategy for the Education Development in Ukraine for 2012-2021», a great attention is paid to the implementation of information and communication technologies in education and ways to achieve it.

Forming economic competence of future vocational training teachers is not only about obtaining professional knowledge and skills, but also about obtaining an economic education, which, in our opinion, can form not only specific economic knowledge and skills relevant in the current conditions, but also reveal social qualities of the individual, as well as create motives for economic activity.

We believe that economic competence of future vocational training teachers by ICT means in higher education institutions will be ensured if the following conditions are met:

- educational process in higher education institutions will correspond to the current trends in the development of ICT means;

- influence factors, economic competence formation mechanisms of future vocational training teachers by ICT means and their interconnection will be revealed;

- pedagogical conditions of the process of forming economic competence of future vocational training teachers by ICT means in higher education institutions will be described;

- model and methodology for future economic education of future vocational training teachers by ICT means in higher education institutions will be created and put into practice.

The main purpose of the informatization process of education is to increase the efficiency of the educational process due to changing illustrative and explanatory methods and mechanical learning skills to mastering the ability of acquiring new knowledge independently, expanding the amount of information and improving its presentation quality, advancing information processing methods and the acquiring by the educational process participants practical skills of applying progressive information technologies in a specific sphere of activity [3, p. 163]. 
Thus, informative competence level of a teacher becomes one of the crucial conditions for successful ICT use in the process of professional preparation of future vocational training teacher and is one of the problems of modern higher economic education informatization, namely: the problem of readiness of higher education institution teachers to work with information and communication technologies, e-learning, professional-purpose software, and the ability to combine means and methods of traditional and computer education [4, p. 114].

Expressing our consent with the opinion of scholars, we believe that the ICT usage in the vocational training process of studying economic courses in higher education institution will be effective in the following cases:

1) they are introduced as a systematic design method (starting with the goal and proceeding to the learning outcomes, implementation, adjustment and subsequent reproduction of the learning process);

2) they are focused on the creative development of the student's personality;

3) personnel and material and technical resources of the university will be mobilized and effectively used;

4) the process of higher education institution informatization will be complex, meet the requirements of the global quality management system and go in two directions - the direct ICT use in both educational process and scientific activity, and for the organization and pedagogical monitoring of future specialists' professional training [4, p. 114].

It should be emphasized that an important condition for successful integration of technologies in education is a professional preparation of future vocational training teachers who operate the new integrated teaching technology systems and facilities. Every future teacher should have the necessary information literacy in understanding how to use the information and communication technologies.

In the course of higher education, there is a necessity to ensure the development of systemic thinking in students, to raise their awareness in the need of ICT usage in management and decision-making process, as well as in study complex economic phenomena. The professors of higher education institutions are faced with a difficult task - to educate future specialists how to rationally use information and communication technologies, their technical capacities and software in performing information and analytical work.

Society that cares about its future needs to be aware of the tremendous opportunities brought by information technologies and to learn how to apply them, first and foremost, in education. There is much to be discussed about the effectiveness and appropriateness of information technology, but not using it would definitely be pointless. Mastering modern information and information and communication technologies, methods of their use in the educational process will contribute to the modernization of education, i.e. improving the quality of future 
vocational training specialists, increasing the accessibility of education, meeting the needs of society in the amount of competitive professionals.

\title{
References:
}

1. Zakon Ukrainy «Pro Natsionalnu prohramu informatyzatsii», vid 13.09.2001 r. № 74/98-VR [Law of Ukraine «On National Informatzation Program» of 13.09.2001. no. $74 / 98-V R]$.

2. Ukaz prezydenta Ukrainy «Natsionalna stratehiia rozvytku osvity v Ukraini na 2012-2020 roky», vid 25.06.2013 № 344/2013 [Decree of the President of Ukraine «National Strategy of the Education Development in Ukraine for 2012-2020» of 25.06.2013 no. № 344/2013]

3. Poiasok, T. B. (2009). Systema zastosuvannia informatsiinykh tekhnolohii u profesiinii pidhotovtsi maibutnikh ekonomistiv: monohrafiia [System of informational technologies usage in professional preparation of future economists in higher educational establishments] (Manuscript of PhD Thesis), Kremenchuk : PE Shcherbatykh O. V.

4. Syrotenko, L. A. (2019). Ekonomichna pidhotovka maibutnikh pedahohiv profesiinoho navchannia zasobamy IKT [Economic training of future vocational training teachers by ICT means]. Pedagogy of formation of creative personality in higher and secondary schools, vol. 66, part 2, pp. 112-115.

\section{WEBINAR AS AN EFFECTIVE METHOD FOR DEVELOPING INFORMATION AND DIGITAL COMPETENCE OF SECONDARY SCHOOL STUDENTS}

\author{
Iana Topolnyk ${ }^{1}$ \\ Larysa Dzyna ${ }^{2}$
}

DOI: https://doi.org/10.30525/978-9934-588-39-6-15

Problem-search methods that contribute to the successful organization of the search, cognitive, creative activity of secondary school students are implemented through forms of project activity, web-quest, webinar, visualization methods and creation of e-portfolio - methods that require active use of information and communication technologies.

Let's take a closer look at the webinar, which is now seen as a tool that creates unique prerequisites for developing key competencies (including

\footnotetext{
${ }^{1}$ State Higher Educational Establishment «Donbas State Pedagogical univeRsity», Ukraine

${ }^{2}$ Bakhmut Comprehensive School Grades I-III № 10 of the

Bakhmut City Council Donetsk region, Ukraine
} 